\title{
Urticaria Causes and Cure with Apt Diet and Anxiety Stabilization: A Case Study Experiment
}

\author{
Ratna Noah \\ Faculty of Science, Asia-Pacific International University \\ ratna@apiu.edu
}

\begin{abstract}
Urticaria is the inflammation of the skin due to a reaction to allergens, which presents itself as swollen pale red bumps or plaques. Urticaria is a very common type of allergic reaction, which can be triggered by food, dust, medicine, irritants, etc. Though the causes may seem infinite, the trigger is specific to an individual. The scientific research method of observation was followed to collect qualitative and quantitative data. The experiment or test element was a single patient with Urticaria. The patient was monitored and data were collected for a year and a half. The case experiment considered two categories, namely: 1. reaction to meat and dairy products were identified and appropriate measures were designed to eliminate all oral intake of said factors and replace it with neutral restorative foods, i.e. a vegan diet. 2. Understanding the mental impact of the patient with regular bodily functions, stress and anxiety stimulants such as peer pressure, were identified and other alternative life-style adaptations were designed and introduced to eliminate or minimize urticaria causes. The method of dietary doses and anxiety stabilization were administered regularly to find a cure for one and a half years. Findings show a major factor that alleviated the effects of diet and anxiety and increased dependence on God by spending more time on learning from the Holy Bible. Gradual implementation of the remedies gradually decreased the outbreaks. The patient stopped medication (Antihistamine) and is on a better lifestyle. One could further study on moderate life-style and its significance to avoid extreme living both on positive and negative aspects of life. Discussions on other factors like situation, demographics, food, lifestyle, and others could be different from time to time and from one individual to another.
\end{abstract}

Keywords: Urticaria causes and cure; aptness of diet; stabilization of anxiety;

\section{INTRODUCTION}

The purpose of this study is to understand the implications of alternative life-style in preventing urticarial diseases that are harmful to human through a case experiment of a patient suffering from chronic urticarial disease. This study was conducted to experiment the benefits of alternative natural treatment and trust and dependence in God when suffering with physical sickness. Since there was no assurance of cure through the prescription drugs, an aspiration to experiment with natural remedies motivated the researcher to undertake the study. Urticaria is also known as hives. Urticaria is reddish rash of bump on the skin, 
sometimes specific to a region of a body and in severe condition it appears throughout the body, it occurs due to allergens for reasons unknown to human, it is itchy and causes irritation and pain in extreme case ("Hives and Your Skin," n.d.). Urticaria commonly occurs below 11 percent of individuals around the globe for many reasons as well as the emerging conditions in our air, water, food, work-life, and other related activities. The cause for urticaria is not specifically known to human. It is a disorder in human body that creates irritation, pain, and anxiety ("Hives (Urticaria)," 2015). It is difficult to diagnose for the exact cause and cure for the symptom is brings only a temporary relief (M. Maurer \& GiménezArnau, 2015).

When a person is suffering from urticaria, it affects the normal life. The quality of life is distorted and often causes post traumatic stress disorders. It is a unique disease that has deeply rooted in the human body. The patient might also go into depression. The only option is to treat the patient(s) with psychotherapeutic therapies as recommended (Gieler et al., 2015). A specialist on urticaria usually prescribes a drug that is only for symptomic treatment and not the cause. This happens to most patients who suffer with urticaria. According to new discovery, it is also classified under autoimmune mechanism. This is a condition that enables the body to self-destruct. Usually, doctors prescribes antihistamines for subsiding symptoms (Marcus Maurer, Zuberbier, Siebenhaar, \& Krause, 2018).

Some studied about idiopathic urticaria and devised models that points out categorization rather than cure of it (Hawe et al., 2016). Human body is so vulnerable in the late 20st century that urticaria is also caused by medication (Stamm, Noble, \& Risher, 1996). If this has occurred in the last century, it is guaranteed to see it in the 21 st century. Wrong practices in cultivation of plants, production of goods and services to gratify selfish desires and keeping money as a false security builds an imbalanced environment that directly affects humans. Latex allergy also contributes to urticaria (Karvonen, 1999).

In this study, we have taken a case of a chronic urticaria patient and treated him with alternate medication and allopathy medication. When eventually allopathy medication was eliminated.

\section{LITERATURE REVIEW}

Urticaria is multi-dimensional and causes discomforts, ill-health, and impossible to validate to a particular extreme individual environmental influence. Exposure to sun can damage the skin. While skin being $17 \%$ of the body weight, and acts as a major protective, decorative, and excretory device, contributing urticaria could be devasting (Stamm et al., 1996). Productivity of the patient is a major 

number

setback during urticaria and costs the patients normal living (Graham et al., 2016). A positive influence over the urticaria patient's by modifying the work and home life to an appropriate balance that suits to a beneficial outcome will promote in healing the cause (Romano-Woodward, 2010).

Allakos Inc has developed a antibodies and produced a prominent product, AK002, which is used to treat gastritis, urticaria, and other related diseases are used as medication for this type of disease.(GlobalData plc, 2019). Urticaria disease also cause frustration, depression, problem relating to housework, sometime exercise might also provoke the disease, and it can affect normal work (Basra \& Shahrukh, 2009).

Urticaria can be treated in a similar way as how tetanus is being treated. Urticaria can also be treated with antihistamines, adrenalin, sedatives, aspirin, codeine, bed rest, and steroids if indicated (Baxley, 1981). Proper diet is advisable like other common diseases. Diet plays a major and initiative role in bring cure to wearied soul. Removing unnatural and replacing with natural health promoting diet will be of a great remedy. Urticaria is the result of many other aspect of living and it could be addressed indirectly by treating diseases like hypertension (Rahman, 1975).

\section{METHODS}

Scientific research method of observation was followed to collect qualitative and quantitative data. In this case research experiment, the test element was a single patient with urticaria. The patient was very closely monitored of the occurrence of the urticaria symptoms through the sleep routines, eating habits, exercise, intake of liquid food, behavior, relationships with family and friends, expressions with the tone of frustration, depression, irritation, restlessness, productivity, and level of temperaments.

Diet patterns were changed from non-vegetarian to vegan in the experimental treatment, prescription drugs were administered in the case of appearance of hives on the body of the patient or due to other emergency. Natural treatment was prescribed by Dr. Enoch and administered by the researcher.

1. Sample size is only one patient suffering from urticarial disease.

2. Data collection was done while the patient was treated with natural and prescription drugs

3. Measured the intensity of the appearance of hives. 


\section{RESULTS}

The prescription of alternative natural diet treatment was given to patient after a thorough examination of the patient for about 5 days. After a month the composition of the prescription of alternative natural diet medication was given.

Table 1. Dr. Enoch's prescription on alternative medication of natural treatment

\begin{tabular}{|c|l|l|}
\hline No & \multicolumn{1}{|c|}{ Timing } & \multicolumn{1}{c|}{ Particulars } \\
\hline 1 & $\begin{array}{l}\text { Empty Stomach in the } \\
\text { morning }\end{array}$ & $\begin{array}{l}\text { Cabbage juice } \\
\text { Aloe vera + Ginger + Soy Curd }\end{array}$ \\
\hline 2 & $7: 30 \mathrm{am}$ Breakfast & Boiled vegetables \\
\hline 3 & $10: 00 \mathrm{am}$ & Water melon juice \\
\hline 4 & $11: 00 \mathrm{am}$ & Flax see tea \\
\hline 5 & $12: 00 \mathrm{pm}$ & Stop pimple powder \\
\hline 6 & $1: 00 \mathrm{pm}$ & Boiled vegetables \\
\hline 7 & $2: 00 \mathrm{pm}$ & Drumstick leaf tea \\
\hline 8 & $4: 00 \mathrm{pm}$ & Corn silk tea \\
\hline 9 & $6: 00 \mathrm{pm}$ Dinner & Fruits \\
\hline 10 & $7: 00 \mathrm{pm}$ & $\begin{array}{l}\text { Chamomile tea } \\
\text { Psyllium Husk }\end{array}$ \\
\hline 11 & & Charcoal, Coriander juice, Green supplement, stop fat \\
\hline 12 & & Sufficient water \\
\hline 13 & & Apply lavender \\
\hline
\end{tabular}

The patient was instructed to follow alternative administered medication strictly for three weeks.

Later after a month Dr. Enoch gave enhanced prescription of alternative life-style medicine for the Urticarial treatment when the intensity of hives increased are shown in the table below:

Table 2. After a month Dr. Enoch's prescription on alternative medication of natural treatment

\begin{tabular}{|c|l|l|}
\hline No & \multicolumn{1}{|c|}{ Time } & \multicolumn{1}{c|}{ Particulars/Prescription of alternative medicine } \\
\hline 1 & $6: 00 \mathrm{am}$ & Aloe Vera drink \\
\hline 2 & $6: 30 \mathrm{am}$ & Warm water with lime \\
\hline 3 & $7: 00 \mathrm{am}$ & Charcoal drink \\
\hline 4 & $8: 00 \mathrm{am}$ & Regular breakfast + 2tsp of flaxseed +10 almonds +10 walnuts \\
\hline 5 & $9: 00 \mathrm{am}$ & Turmeric drops $(4)$ \\
\hline 6 & $10: 00 \mathrm{am}$ & Basil leaves + peppermint leaves + thyme leaves \\
\hline 7 & $11: 00 \mathrm{am}$ & Apple juice \\
\hline & $12: 00 \mathrm{pm}$ & $\begin{array}{l}\text { Anti-allergy juice }- \text { carrot +onion }+ \text { cabbage }+ \text { capsicum }+ \text { parsley }+ \\
\text { celery }+ \text { cucumber juices }\end{array}$ \\
\hline & 1:00 pm & Regular lunch +2 tsp of Flaxseed \\
\hline
\end{tabular}


Abstract Proceedings International Scholars Conference, Volume 7 Issue 1, October 2019, pp. page number

\begin{tabular}{|l|l|l|}
\hline & $2: 30 \mathrm{pm}$ & Milk thistle tea \\
\hline $4: 00 \mathrm{pm}$ & Fennel tea \\
\hline $4: 30 \mathrm{pm}$ & Stop pimple power drink \\
\hline 5:30 pm & Turmeric drops (4) \\
\hline 6:00 pm & Dinner - Fruits (especially pomegranates) \\
\hline 7:30 pm & Psyllium husk \\
\hline
\end{tabular}

Eat everyday antihistamine food which are

1. Black rice

2. Onion

3. Parcel \& broccoli

4. Apples

5. Basil \& ginger

6. Sweet potato

7. Mung bean sprout

Table 3. Supplements Prescription during a day

\begin{tabular}{|c|l|c|c|c|}
\hline No & \multicolumn{1}{|c|}{ Name of the Supplements } & $\begin{array}{c}\text { Morning } \\
\text { (tsp) }\end{array}$ & $\begin{array}{c}\text { Afternoon } \\
\text { (tsp) }\end{array}$ & $\begin{array}{c}\text { Night } \\
\text { (tsp) }\end{array}$ \\
\hline 1 & C. licorice & 2 & - & 3 \\
\hline 2 & C. Ashwagantha & 2 & - & 2 \\
\hline 3 & T. Vitamin C -500mg & 1 & - & 1 \\
\hline 4 & Zinc supplement & 1 & - & - \\
\hline 5 & C. Sarsaparilla & 1 & - & 1 \\
\hline 6 & C. Phyllanthus neuri & 1 & - & 1 \\
\hline 7 & Probiotics & 1 & 1 & 1 \\
\hline \multicolumn{2}{|l}{ Do regular exercise. }
\end{tabular}

Table 4. Reporting Research Result

\begin{tabular}{|c|c|c|c|}
\hline No & Time/Duration & Symptoms/Treatment & Evidence/Results \\
\hline 1 & December 2017 & $\begin{array}{l}\text { First appearance of hives - consulted a } \\
\text { doctor and was given prescription } \\
\text { drugs - hydroxyzine and steroid. }\end{array}$ & $\begin{array}{l}\text { Hives appeared when the } \\
\text { patient stopped the medication. }\end{array}$ \\
\hline 2 & $\begin{array}{l}\text { January - March } \\
2018\end{array}$ & $\begin{array}{l}\text { Every day the drug was administered } \\
\text { before Breakfast. }\end{array}$ & $\begin{array}{l}\text { The patient was asked not to } \\
\text { take the prescription drug for a } \\
\text { while. During this period, when } \\
\text { the body was out of the } \\
\text { influence of the drugs, hives } \\
\text { appeared. At the appearance of } \\
\text { the hives the patient takes the } \\
\text { drugs and the hives get } \\
\text { suppressed or do not appear. }\end{array}$ \\
\hline
\end{tabular}




\begin{tabular}{|c|c|c|c|}
\hline 3 & $\begin{array}{l}\text { April \& May } \\
2018\end{array}$ & $\begin{array}{l}\text { After the breakfast, prescription drugs } \\
\text { were administered every alternative } \\
\text { day } \\
\text { Dr. Enoch's prescription on alternative } \\
\text { medication was given along with the } \\
\text { prescription drugs. At this point, the } \\
\text { patient was advised not to eat non- } \\
\text { vegetarian food but vegan diet during } \\
\text { the treatment. }\end{array}$ & $\begin{array}{l}\text { Hives appeared in the similar } \\
\text { pace and never reduced in its } \\
\text { intensity. }\end{array}$ \\
\hline 4 & $\begin{array}{l}\text { June, July, and } \\
\text { August } 2018\end{array}$ & $\begin{array}{l}\text { Prescription drugs were taken once in } \\
\text { three days. }\end{array}$ & $\begin{array}{l}\text { Improvement was seen. } \\
\text { Medication loose its effect only } \\
\text { on the third day. }\end{array}$ \\
\hline 5 & $\begin{array}{l}\text { End of August } \\
2018\end{array}$ & $\begin{array}{l}\text { Prescription drugs were taken once in } \\
\text { three days. }\end{array}$ & \\
\hline 6 & $\begin{array}{l}\text { September } 2018- \\
\text { January } 2019\end{array}$ & $\begin{array}{l}\text { Changed the university and moved to } \\
\text { China. } \\
\text { Followed vegan diet, engaged in } \\
\text { helping new friends to study bible and } \\
\text { increased involvement in church } \\
\text { activities and increased time spent on } \\
\text { learning God's word. }\end{array}$ & $\begin{array}{l}\text { Anxiety reduced, reduced peer } \\
\text { pressure, there was a gradual } \\
\text { decrease in the outbreak of } \\
\text { hives, sometime the medication } \\
\text { was taken once in four days. }\end{array}$ \\
\hline 7 & February 2019 & $\begin{array}{l}\text { Prescription drug was taken once in a } \\
\text { week. }\end{array}$ & $\begin{array}{l}\text { The intensity of hives were } \\
\text { reduced and became more } \\
\text { prevalent to a particular region } \\
\text { rather than the whole body. }\end{array}$ \\
\hline 8 & March 2019 & $\begin{array}{l}\text { Prescription drugs were stopped. The } \\
\text { patient stopped antihistamine drug. }\end{array}$ & $\begin{array}{l}\text { No more appearance of hive. } \\
\text { Anxiety was normal, no peer } \\
\text { pressure, alternative life-style } \\
\text { adaptations were continued. }\end{array}$ \\
\hline
\end{tabular}

The recovered patient's level of anxiety was stabilized, exhibited much patience and perseverance in performing well in the academics, peer pressure was in a manageable level, increased dependence on God in reflecting His character was supreme compared to before urticaria. Patient's university influencers were very matured and had enhanced experience when socialized.

\section{DISCUSSION}

This experiment was conducted to learn the impact a patient could obtain from the alternative natural treatment. On an extreme thinking of the prescription drugs (antihistamine) would only treat the symptom rather than the cause of urticaria. This reason of towards the desire of curing urticaria initiated a search for cure for the cause through alternative life-style treatment. The importance of the study is to understand the impact of alternative medication on treating urticarial causes and cure with apt diet. This experiment was conducted during December 2017 to March 2019 and after that there was follow up with a vegan diet. The 

number

ending time was not scheduled but it was based on the result of the urticarial cure. Later, after March 2019, when the experiment test subject ate eggs there were appearances of hives. This showed the right diet for curing urticarial causes was only a vegan diet. Self-control of the patient was a phenomenal step towards maintaining a vegan diet.

The findings are unlike the earlier findings about the cure of urticaria. Most studies were only pointing out the symptoms and its impact of these symptoms but not the cure of it. Definitive in the cure with the prescription drugs were only temporary rather than permanent. This study is specifically pointing to the cure of chronic urticarial disease. There is an absolute cure in the alternative natural treatment of urticarial disease with natural food and learning to live by the God's precepts. It is significant to say, though the prescription drugs did not bring permanent cure, it aided in the temporary remedy. This is the limitation of the prescription drug. Life-style change, trust in God for healing of chaotic circumstances and an urge to reflect and reflect his character is the greatest healing it can bring to the human body. This experiment proves it beyond measure a cure for urticaria.

Since, it is case experiment, the study is limited to the examination of one patient. Future study could be done on many patients suffering with urticarial diseases.

\section{Conclusion}

The case experiment ended with the cure of the patient and the patient is living happily with his endeavors with urticaria free. Stopping of the prescription drugs and follow up of the natural life-style administered treatment with natural remedies is the best result shown in the experiment. Living in a growing economy, the demands of the workplace, following complex regulation and an urge in increased employee productivity, the adversity that results from the emerging global economy and so on, calls for our attention to change our life-style that will keep our bodies disease free to enjoy healthy living that is worth beyond visions one could think of.

\section{REFERENCES}

Basra, M. K., \& Shahrukh, M. (2009). Burden of skin diseases. Expert Review of Pharmacoeconomics \& Outcomes Research; London, 9(3), 271-283. http://dx.doi.org/10.1586/erp.09.23

Baxley, L. M. (1981). Tetanus is Still Deadly. Occupational Health Nursing; Atlanta, 29(8), $40-42$. https://search.proquest.com/docview/1013442313/citation/630C043088D24CE9PQ/1 4 
Gieler, U., Gieler, T., Schut, C., Niemeier, V., Peters, E. M., \& Kupfer, J. (2015). Quality of Life and Comorbidities in Urticaria: What Is Known? Current Dermatology Reports, 4(2), 77-82. https://doi.org/10.1007/s13671-015-0105-6

GlobalData plc. (2019). Allakos Inc (ALLK)—Pharmaceuticals \& Healthcare-Deals and Alliances Profile. Retrieved from https://search.proquest.com/docview/2183766623/abstract/630C043088D24CE9PQ/1

Graham, J., McBride, D., Stull, D., Halliday, A., Alexopoulos, S. T., Balp, M.-M., ... Alan Brennan, T. Z. (2016). Cost Utility of Omalizumab Compared with Standard of Care for the Treatment of Chronic Spontaneous Urticaria. PharmacoEconomics; Auckland, 34(8), 815-827. http://dx.doi.org/10.1007/s40273-016-0412-1

Hawe, E., McBride, D., Balp, M.-M., Tian, H., Halliday, A., \& Stull, D. E. (2016). EQ-5D Utilities in Chronic Spontaneous/Idiopathic Urticaria. PharmacoEconomics; Auckland, 34(5), 521-527. http://dx.doi.org/10.1007/s40273-015-0375-7

Hives and Your Skin. (n.d.). Retrieved September 30, 2019, from WebMD website: https://www.webmd.com/skin-problems-and-treatments/guide/hives-urticariaangioedema

Hives (Urticaria). (2015, January 12). Retrieved September 30, 2019, from ACAAI Public Website website: https://acaai.org/allergies/types-allergies/hives-urticaria

Karvonen, C. A. (1999). Latex allergy in health care workers: What are the risks? AAOHN Journal; Thorofare, 47(11), 519-525. Retrieved from https://search.proquest.com/docview/219354630/abstract/3D8D13E5153A42C9PQ/5

Maurer, M., \& Giménez- Arnau, A. M. (2015). What is urticaria? Expert opinion from the 1st Global Urticaria Forum. Journal of the European Academy of Dermatology and Venereology, 29(S3), 1-2. https://doi.org/10.1111/jdv.13187

Maurer, Marcus, Zuberbier, T., Siebenhaar, F., \& Krause, K. (2018). Chronic urticaria What does the new guideline tell us? JDDG: Journal Der Deutschen Dermatologischen Gesellschaft, 16(5), 584-593. https://doi.org/10.1111/ddg.13531

Rahman, J. C. (1975). Hypertension. Occupational Health Nursing; Atlanta, 23(1), 17-20. Retrieved

from https://search.proquest.com/docview/1012768999/citation/E056C0D913C04B86PQ/1

Romano-Woodward, D. (2010). Handle with care. Occupational Health; Sutton, 62(8), $17-$ 19. https://search.proquest.com/docview/746766828/abstract/4BF1E09C4A5E4A07PQ/1

Stamm, P. L., Noble, S. L., \& Risher, L. L. (1996). A review of common dermatological problems. Drug Topics; Monmouth Junction, 140(23), 134-143. Retrieved from https://search.proquest.com/docview/205053651/abstract/3D8D13E5153A42C9PQ/4 